\title{
PENGARUH CURRENT RATIO, DEBT TO EQUITY RATIO, DAN EARNING PER-SHARE TERHADAP HARGA SAHAM
}

(Studi Empiris pada Perusahaan Sektor Industri Consumer Goods yang Listing di Bursa Efek Indonesia Periode 2008-2012)

\author{
Arry Widodo ${ }^{1}$, Renda Puspita Dewi ${ }^{2}$ \\ ${ }^{1}$ Fakultas Ekonomi, Universitas Telkom \\ email: arry.widodo@gmail.com \\ ${ }^{2}$ Fakultas Ekonomi, Universitas Telkom \\ email: rendapuspitad@gmail.com
}

\begin{abstract}
This study also aimed to determine the effect of Current Ratio (CR), Debt to Equity Ratio (DER), and Earning per Share (EPS) to the Price Stock either partially or simultaneously. Secondary data collected based on time series and cross section from the 2008-2012 from 26 companies Costumer Goods sector. By using panel data regression analysis techniques and the Chow test and Hausman test shows that the model used in the estimation of the data is the Random Effect Model. The results showed that the independent variables, EPS significant effect on stock prices. While CR and partially DER no significant effect on stock prices. Simultaneously, CR, DER, and EPS significant effect on stock prices.
\end{abstract}

Keywords: Current Ratio, Debt to Equity Ratio, Earnings per Share, Price Stock

\section{ABSTRAK}

Penelitian empiris mengenai CR, DER, EPS dan harga saham telah banyak dilakukan tetapi menghasilkan simpulan yang beragam Adanya berbagai perbedaan hasil penelitian sebelumnya menarik perhatian penulis untuk melakukan penelitian lebih lanjut mengenai pengaruh $\mathrm{CR}, D E R$, dan EPS terhadap harga saham perusahaan Populasi dalam penelitian ini adalah perusahaan-perusahaan yang termasuk dalam sektor industri consumer goods yang listing di BEI periode 2008 - 2012 yang berjumlah 40 perusahaan dan sampel ditentukan secara purposive sampling. Hasil penelitian menunjukan variabel kemampuan bayar kewajiban jangka pendek (CR), kewajiban bayar bunga (DER), dan laba per lembar saham (EPS) memiliki pengaruh signifikan secara simultan dengan nilai kontribusi sebesar $58.4820 \%$ dalam mempengaruhi harga saham.

Kata Kunci: Kemampuan bayar kewajiban jangka pendek (CR), kewajiban bayar bunga (DER), dan laba per lembar saham (EPS) 


\section{PENDAHULUAN}

Krisis ekonomi global pada tahun 2008 berpengaruh sangat signifikan terhadap perekonomian dunia. Krisis tersebut menimbulkan pengeringan likuiditas di pasar keuangan yang mempengaruhi memburuknya kondisi pasar modal global

(indonesiarecovery.com).Memburu knya kondisi pasar modal global ini juga membawa dampak pasar modal Indonesia yang direpresentasikan indeks harga saham di BEI. Indeks harga saham semua sektor yang ada di BEI mengalami penurunan pada waktu krisis.Tetapi jika dilihat dari persentase penurunannya, maka dari semua sektor yang mengalami penurunan yang terendah adalah sektor industri barang konsumsi yaitu turun sebesar $25.04 \%$. Hal ini menunjukkan bahwa dari seluruh sektor yang ada di BEI, sektor industri barang konsumsi lebih mampu bertahan pada masa krisis. Menurut pengamat pasar modal Jimmy Dimas Wahyu (investasi.Kontan.co. id), di tengah isu perlambatan ekonomi global, sektor yang paling bisa bertahan dan berkontribusi kepada pengangkatan IHSG adalah sektor industri barang konsumsi. Dalam kondisi perekonomian global yang bergejolak, sektor-sektor yang memberikan pemenuhan kebutuhan domestik masih bisa stabil.

Setelah krisis, sektor consumer goods memiliki pertumbuhan yang positif sepanjang tahun 2009-2012. Akan tetapi tingkat pertumbuhannya terus mengalami penurunan sampai tahun 2012 yaitu sebesar $18.99 \%$. Penurunan tingkat pertumbuhan indeks harga saham sektoral consumer goods terjadi karena adanya fluktuasi harga saham perusahaan yang tergabung dalam sektor consumer goods. Fluktuasi harga saham tercermin dari pertumbuhan negatif dan positif dari pergerakan harga saham. Penurunan harga saham atau pertumbuhan harga saham yang negatif merupakan indikasi dari kinerja perusahaan yang mengalami penurunan (Fahmi, 2012:276). Kinerja perusahaan yang menurun 
dalam jangka panjang akan memberi dampak berkurangnya bagian laba untuk investor dan capital loss apabila investor menjual sahamnya. Oleh karena itu dibutuhkan analisis lebih lanjut dari para calon investor terhadap kinerja perusahaan sebelum mengambil keputusan investasi untuk menghindari risiko.

\section{Analisis fundamental} merupakan salah satu yang bisa dilakukan oleh investor sebelum melakukan keputusan investasi. Analisis fundamental bisa dilihat dari rasio-rasio keuangan yang terdapat pada laporan keuangan perusahaan.Rasio likuiditas, solvabilitas dan profitabilitas secara umum menjadi perhatian investor karena secara dasar dianggap sudah merepresentasikan analisis awal tentang kondisi suatu perusahaan (Fahmi, 2012:58). Berdasarkan penelitian yang dilakukan oleh Simatupang (2010) CR sebagai rasio likuiditas, DER sebagai rasio solvabilitas, dan EPS sebagai rasio profitabilitas berpengaruh signifikan terhadap harga saham perusahaan sektor consumer good yang terdaftar di BEI.

Penelitian empiris mengenai CR, DER, EPS dan harga saham telah banyak dilakukan tetapi menghasilkan simpulan yang beragam. Dalam penelitian Sidabutar (2012) CR dan DER secara parsial tidak berpengaruh signifikan terhadap harga saham. Sujatmiko (2011) menemukan bahwa CR berpengaruh signifikan terhadap harga saham dan DER tidak berpengaruh terhadap harga saham.Sasono menyimpulkan bahwa EPS berpengaruh signifikan terhadap harga saham, sedangkan CR dan $D E R$ secara parsial tidak berpengaruh terhadap harga saham.Adanya berbagai perbedaan hasil penelitian sebelumnya tersebut menarik perhatian penulis untuk melakukan penelitian lebih lanjut mengenai pengaruh $\mathrm{CR}, D E R$, dan EPS terhadap harga saham perusahaan sehingga dapat menjadi pertimbangan investor sebagai pilihan alternatif dalam menginvestasikan modalnya 
sehingga mampu memperoleh hasil yang maksimal dengan memperhitungkan berbagai aspek atau resiko yang akan dihadapi dalam peneneman modal serta pada umumnya investor akan menganalisis laporan keuangan perusahaan khususnya pada laporan laba rugi.

\section{RERANGKA KONSEPTUAL DAN HIPOTESIS}

Secara sederhana saham dapat didefinisikan sebagai tanda penyertaan atau pemilikan seseorang atau badan dalam suatu perusahaan. Wujud saham berupa selembar kertas yang menerangkan bahwa pemilik kertas tersebut merupakan pemilik perusahaan yang menerbitkan kertas tersebut (Darmadji dan Fakhruddin, 2011:5). Imbalan yang akan diperoleh dengan kepemilikan saham adalah kemampuannya memberikan keuntungan baik berupa dividen atau capital gain. Dividen diterima bila emiten mampu menghasilkan laba. Sedangkan capital gain akan diperoleh bila ada kelebihan harga jual di atas harga beli.
Harga pasar suatu saham pada dasarnya adalah merupakan harga yang telah disepakati oleh penjual dan pembeli pada saat saham diperdagangkan. Harga pasar sebuah saham di Bursa Efek (pasar sekunder) dapat berubah naik dan turun dalam hitungan waktu yang cepat. Salah satu faktor yang menyebabkan perubahan harga saham adalah kinerja perusahaan (Fahmi, 2012:276). Saham saham perusahaan yang baik kinerjanya akan mempunyai nilai yang tinggi. Hal ini disebabkan karena saham tersebut diminati oleh banyak investor yang membuat permintaan akan saham tersebut melebihi penawarannya sehingga berdampak pada naiknya harga saham tersebut. Sebaliknya, buruknya kinerja suatu perusahaan dapat mengakibatkan jatuhnya harga saham perusahaan tersebut.

Penilaian kinerja keuangan merupakan faktor penting bagi investor. Laporan keuangan merupakan sinyal informasi kinerja perusahaan yang diberikan perusahaan untuk investor. 
Berdasarkan Signalling Theory (Teori Sinyal) yang dikemukakan oleh Michael Spence (Oktaviana \&Wahyuni,2011:4), terdapat asumsi adanya asimetri informasi antara manajemen dengan investor. Manajemen mempunyai informasi yang akurat tentang nilai perusahaan yang tidak diketahui oleh investor. Dengan memberikan suatu sinyal, pihak pengirim (manajemen) berusaha memberikan potongan informasi relevan yang dapat dimanfaatkan oleh pihak penerima (investor).

Manajemen menyajikan laporan keuangan dan pihak luar perusahaan memanfaatkan informasi tersebut untuk membantu membuat keputusan. Investor yang ingin membeli atau menjual saham bisa terbantu dengan memahami dan menganalisis laporan keuangan hingga selanjutnya bisa menilai perusahaan mana yang mempunyai prospek yang menguntungkan di masa depan (Fahmi, 2012:22). Analisis laporan keuangan tersebut memerlukan ukuran tertentu. Ukuran yang umum digunakan adalah rasio keuangan. Rasio keuangan sebagai alat ukur kondisikondisi keuangan suatu perusahaan dengan jalan membandingkan dua buah variabel yang diambil dari laporan keuangan perusahaan, baik daftar neraca maupun rugi-laba (Gitman, 2009:56).

Analisis rasio bermanfaat bagi manajemen untuk perencanaan dan pengevaluasian prestasi atau kinerja perusahaan. Selanjutnya menurut (Hidayat, 2010:117) bahwa dalam pengambilan keputusan investasi, investor menggunakan analisis fundamental berupa analisis rasio. Rasio keuangan yang akan dibahas dalam penelitian ini adalah $C R$, $D E R$, dan EPS. Ditentukannya rasio-rasio tersebut dalam penelitian ini karena beberapa faktor tersebut dinilai sangat dominan pengaruhnya terhadap perubahan harga saham.

Hubungan antar Variabel Penelitian

Kemampuan Bayar Kewajiban Jangka Pendek (CR) terhadap harga saham

$C R$ merupakan rasio yang digunakan untuk mengukur 
kemampuan aset lancar perusahaan untuk memenuhi kewajiban jangka pendeknya. Apabila perusahaan tidak mampu memenuhi kewajiban jangka pendeknya, maka perusahaan juga mengalami kesulitan dalam memenuhi kewajiban jangka panjangnya. Kegagalan dalam membayar kewajiban dapat menyebabkan kebangkrutan perusahaan (Fahmi, 2012:58). Investor akan menghindari perusahaan yang memiliki tingkat risiko kebangkrutan yang tinggi, bagi investor yang telah melakukan investasi saham pada perusahaan yang berisiko tinggi akan menjual sahamnya sebelum mengalami kerugian lebih lanjut. Semakin banyak investor yang menjual saham akan mengakibatkan harga saham perusahaan tersebut turun.

Kewajiban Bayar Bunga (DER) terhadap harga saham

Dari pihak pemegang saham, rasio DER yang tinggi akan mengakibatkan pembayaran bunga tinggi yang pada akhirnya akan mengurangi pembagian laba atas saham (Darsono dan Ashari, 2005:54). Selain itu DER yang tinggi memberikan arti bahwa pendanaan perusahaan untuk aset nya lebih banyak dibiayai oleh hutang, apabila terjadi kebangkrutan aset tersebut lebih banyak digunakan untuk menutup hutang dari pada bagian untuk pemilik modal.

Profitabilitas (EPS) terhadap harga saham

EPS menggambarkan profitabilitas perusahaan yang tergambar pada setiap lembar saham. Informasi EPS akan diberikan secara periodik oleh perusahaan. Dalam jangka panjang, akan menghasilkan suatu trend EPS yang bisa memberi gambaran kenaikan atau penurunan kemampuan perusahaan dalam menghasilkan laba perlembar sahamnya. Peningkatan kemampuan perusahaan dalam menghasilkan laba atas modal yang diinvestasikan para pemegang saham akan memberikan pengaruh 
positif terhadap harga saham. Makin tinggi nilai EPS tentu saja menggembirakan pemegang saham karena makin besar laba yang disediakan untuk pemegang saham dan kemungkinan peningkatan jumlah dividen yang dterima pemegang saham (Darmadji dan Fakhruddin, 2011:154). Ini akan mendorong investor untuk melakukan investasi yang lebih besar lagi sehingga harga saham perusahaan akan meningkat.

\section{Gambar 2.1 Kerangka Pemikiran}

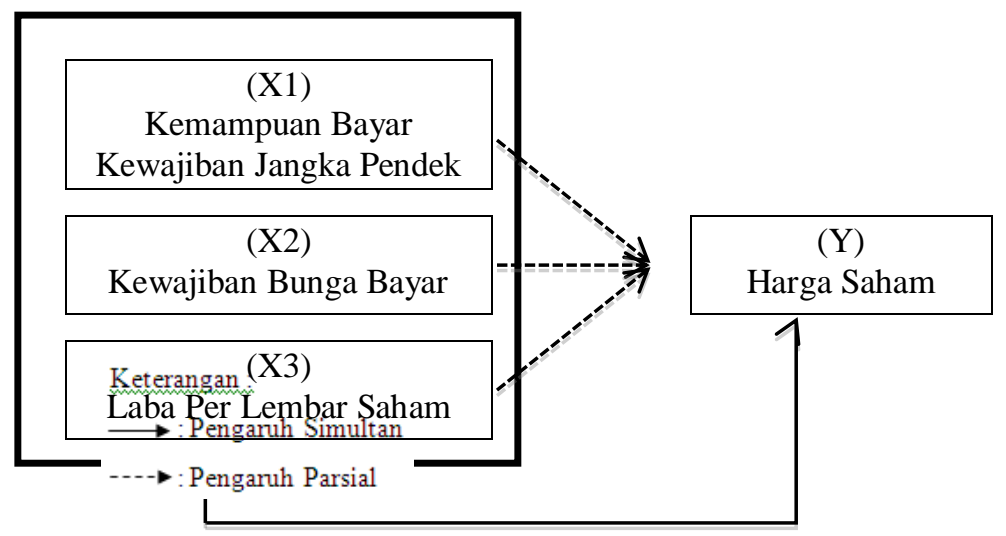

Dari gambar tersebut, terhadap kinerja perusahaan menjelaskan bahwa dalam tersebut akan direspons oleh pasar penelitian ini ingin mengetahui pengaruh rasio keuangan yang dan membawa dampak terhadap nilai perusahaan. Jika kinerja terdiri dari Kemampuan Bayar perusahaan baik maka harga saham Kewajiban Jangka Pendek (CR), dari perusahaan tersebut juga akan Kewajiban Bayar Bunga (DER) mengalami kenaikan karena terhadap harga saham, dan Laba Per berhasil mengundang lebih banyak Lembar Saham (EPS) terhadap investor untuk membeli sahamnya, harga saham baik secara simultan maupun parsial. Peninjauan hukum permintaan, semakin banyak permintaan maka harga akan naik. 


\section{METODE PENELITIAN}

Penelitian ini dirancang untuk mengetahui pengaruh kinerja keuangan perusahaan melalui rasio keuangan $C R, D E R$, dan EPS terhadap harga saham perusahaanperusahaan yang termasuk dalam sektor consumer good periode 2008-2012.Jenis penelitian yang digunakan adalah deskriptif verifikatif, metode dalam penelitian ini adalah metode kuantitatif.

Tabel 3.1 Variabel Operasional Populasi dan Sampel

\begin{tabular}{|c|c|c|}
\hline Variabel & Indikator & Skala \\
\hline (X1) & Aktiva Lancar & Rasio \\
Kemampu & Kewajiban Lancar & \\
an Bayar & & \\
Kewajiban & & \\
Jangka & & \\
Pendek & & \\
\hline (X2) & $\frac{\text { Total Kewajiban }}{\text { Total Ekuitas }}$ & \\
Kewajiaba & & \\
n Bunga & & \\
Bayar & & Rasio \\
(X3) & Laba Bersih Setelah Pajak \\
Laba Per & Jumlah Saham Yang Beredar & \\
Lembar & & \\
Saham & & \\
\hline (Y) & Harga Saham Pada Saat & Rasio \\
Harga & Penutupan & \\
Saham & & \\
\hline
\end{tabular}

Populasi dalam penelitian ini adalah perusahaan-perusahaan yang termasuk dalam sektor industri consumer goods yang listing di BEI periode 2008 - 2012 yang berjumlah 40 perusahaan. Adapun sampel ditentukan secara purposive sampling dengan kriteria sebagai berikut:

1. Perusahaan tersebut terdaftar di BEI selama periode 2008-2012,

2. Perusahaan tersebut mempublikasikan laporan keuangan lengkap selama periode 2008-2012,

3. Perusahaan tersebut menghasilkan laba (earning) selama periode 2008-2012, karena pada penelitian ini menggunakan transformasi logaritma natural dimana data negatif akan hilang setelah ditransformasi sehingga peneliti menghindari adanya data negatif.

4. Perusahaan tersebut tidak mengalami delisting atau merger selama periode 2008-2012. Berdasarkan kriteria di atas peneliti mengambil 26 perusahaan sebagai sampel dari 40 perusahaan 
sektor industri consumer good yang listing di Bursa Efek Indonesia periode 2008 - 2012.

\section{Teknik Pengumpulan Data}

Teknik pengumpulan data dalam penelitian ini adalah studi kepustakaan (library research). Studi kepustakaan ini dilakukan dengan mengumpulkan bahanbahan yang berguna bagi analisis yang akan dilakukan selanjutnya. Bahan-bahan yang dibutuhkan dapat berasal dari text book, jurnal, skripsi, tesis, laporan keuangan perusahaan, website, dan lain-lain. Untuk penelitian ini, data yang dikumpulkan bersumber dari data sekunder. Sumber data sekunder untuk penelitian ini diambil dari IDX Yearly Statistic, dan laporan keuangan tahunan emiten yang dikeluarkan oleh website Bursa Efek Indonesia yaitu www.idx.co.id serta ringkasan laporan keuangan yang dikeluarkan oleh PT. Indonesian Capital Market Elektronic Library (ICaMEL).

\section{Teknik Analisis Data}

Penelitian ini menggunakan data panel (pooled data) yaitu gabungan data time series dan cross section. Metode analisis yang akan digunakan pada penelitian ini adalah model regresi panel data. Adapun perumusan model tersebut adalah sebagai berikut:

$Y=\alpha+\beta_{1} X_{1}+\beta_{2} X_{2}+\beta_{3} X_{3}+\varepsilon$

Dimana :

$\begin{array}{llll}\mathrm{Y} & = & \text { Harga saham } \\ \mathrm{X}_{1} & = & & \\ \mathrm{X}_{2} & = & & \\ \mathrm{X}_{3} & = & & \\ \alpha & = & & \\ \beta_{1} & = & \text { Konstanta } & \\ \beta_{2} & = & \text { Koefisien regresi } C R \\ D E R & & \\ \beta_{3} & = & \text { Koefisien } & \text { regresi } \\ E P S & & \\ \varepsilon & & & \\ \varepsilon & & \end{array}$


Untuk memilih pendekatan yang digunakan untuk mengestimasi model regresi data panel, yaitu Common Effect Model, Fixed Effect Model atau Random Effect Model dilakukan uji Chow dan uji Hausman. Sebelum uji hipotesis regresi panel data digunakan, maka dilakukan uji asumsi-asumsi yang mendasari penggunaan persamaan regresi. Asumsi klasik yang harus terpenuhi dalam model regresi linier yaitu residual terdistribusi normal, tidak adanya multikolinearitas, tidak adanya hereroskedastisitas, dan tidak adanya autokorelasi pada model regresi (Setiawan dan Kusrini, 2010 : 65 - 67).

Standarisasi data yang di gunakan menggunakan uji $\mathrm{t}$ (uji parsial) dan uji $F$ (uji simultan) dengan tingkat signifikansi yang digunakan sebesar 5\%. Uji koefisien determinasi dilakukan untuk mengetahui ketepatan model regresi dalam memprediksi variabel dependennya. Nilai koefisien determinasi yang digunakan adalah Adjusted R Square. Besarnya
Adjusted R Square menggambarkan besarnya variabel bebas dalam menjelaskan variabel terikat.

\section{HASIL PENELITIAN DAN PEMBAHASAN}

\section{Perkembangan $C R$ Perusahaan} Sektor Industri Consumer Goods Tahun 2008 - 2012

Rata-rata 26 perusahaan 26 perusahaan sektor Consumer Goods terhitung 3,04 terdapat sekitar $\mathrm{Rp}$ 3,04 aktiva lancar untuk memenuhi tiap-tiap Rp 1 kewajiban yang akan jatuh tempo. Hal ini mengindikasikan kondisi industri Consumer Goods yang likuid. Secara individual, terdapat 10 perusahaan yang rata-rata $C R$-nya berada di atas rata-rata $C R$ industri costumer goods selama periode penelitian diantaranya CEKA, DLTA, DVLA, KLBF, MERK, SQBI, SQBB, TSPC, MRAT, dan TCID. Rata-rata $C R$ tertinggi selama tahun 2008 - 2012 dimiliki oleh PT Mandom Indonesia Tbk (TCID) yaitu sebesar 9.10 kali. Hal ini terjadi karena TCID memiliki rata-rata aktiva lancar yang lebih 
besar dari rata-rata kewajiban lancarnya. Pos aktiva lancar yang paling dominan adalah piutang usaha dan persediaan.

Terdapat 16 perusahaan yang rata-rata $C R$-nya di bawah rata-rata $C R$ industri costumer goods yaitu AISA, INDF, MLBI, MYOR, PSDN, SKLT, STTP, ULTJ, GGRM, HMSP, INAF, KAEF, PYFA, UNVR, KDSI, LMPI. Diantara keenambelas perusahaan tersebut PT Unilever Indonesia Tbk (UNVR) memiliki rata-rata $C R$ terendah yaitu sebesar 0.85 kali. Hal ini terjadi karena UNVR memiliki rata-rata kewajiban lancar yang lebih tinggi dibandingkan dengan rata-rata aktiva lancar selama tahun 2008-2012.UNVR memaksimalkan utang usahanya dalam membiayai aktivitas operasionalnya.

\section{Perkembangan $D E R$ Perusahaan}

Sektor Industri Consumer Goods

Tahun 2008 - 2012

Rata-rata DER dari 26 perusahaan sektor Consumer Goods terhitung 0.81 yang berarti bahwa
26 perusahaan sektor Consumer Goods selama periode penelitian 2008 - 2012 memiliki rata-rata sumber pendanaan Rp.0.811791 dari kreditur untuk tiap-tiap pendanaan $\mathrm{Rp} 1$ dari pemilik perusahaan. Secara individual, terdapat 11 perusahaan yang ratarata $D E R$-nya berada di atas ratarata DER industri costumer goods selama periode penelitian diantaranya AISA, CEKA, INDF, MLBI, MYOR, PSDN, SKLT, HMSP, INAF, UNVR, dan KDSI. Rata-rata $D E R$ tertinggi dimiliki oleh PT Multi Bintang Indonesia Tbk (MLBI) yaitu sebesar 2.84 kali. Hal ini terjadi karena rata-rata sumber pendanaan dari kreditur lebih tinggi dibandingkan dengan rata-rata sumber pendanaan dari pemilik modal. MLBI memiliki nilai buku saham yang relatif sedikit jika dibandingkan dengan perusahaan lainnya yaitu sebesar Rp. 21.070.000.000. Untuk mendanai aktivitas operasional dan investasinya, MLBI lebih mengandalkan utang jangka pendek yaitu utang usaha dan utang dari 
bank. Selain itu MLBI mengoptimalkan pembagian cash dividen, sehingga bagian untuk laba ditahan yang merupakan sumber pendanaan ekuitas pemilik modal menjadi semakin sedikit.

Terdapat 15 perusahaan yang rata-rata $D E R$-nya di bawah ratarata DER industri costumer goods yaitu DLTA, STTP, ULTJ, GGRM, DVLA, KAEF, KLBF, MERK, PYFA, SQBB, SQBI, TSPC, MRAT, TCID, dan LMPI. Diantara kelimabelas perusahaan tersebut PT Mandom Indonesia Tbk (TCID) memiliki rata-rata $D E R$ terendah yaitu sebesar 0.12 kali.Hal ini terjadi karena TCID memiliki ratarata sumber pendanaan dari pemilik modal lebih tinggi dibandingkan dengan sumber pendanaan dari kreditur. TCID memiliki nilai buku saham yang relatif besar dibandingkan dengan perusahaan lain yaitu sebesar Rp. 100.533.333.500 sebagai sumber pendanaan dari pemilik modal. Selain itu TCID memiliki tingkat laba ditahan yang lebih besar dibandingkan dengan bagian untuk dividen sehingga akan menambah jumlah ekuitas yang dimiliki.

\section{Perkembangan EPS Perusahaan} Sektor Industri Consumer Goods Tahun 2008 - 2012

Rata-rata $E P S$ dari 26 perusahaan sektor Consumer Goods terhitung 2136,45 yang berarti bahwa 26 perusahaan sektor Consumer Goods selama periode penelitian 2008 - 2012 memiliki rata-rata kemampuan menghasilkan laba per lembar sahamnya sebesar Rp. 2.136,45. Secara individual, terdapat 4 perusahaan yang rata-rata $E P S$-nya berada di atas rata-rata EPS industri costumer goods selama periode penelitian diantaranya DLTA, MLBI, MERK, dan SQBB. Rata-rata EPS tertinggi dimiliki oleh PT Multi Bintang Indonesia Tbk (MLBI) yaitu sebesar Rp. 21.562,55. Tingkat laba bersih MLBI selalu mengalami peningkatan dari tahun 2008 sampai dengan tahun 2012, dengan ratarata laba bersih sebesar $\mathrm{Rp}$. 405.888.000.000. Selain itu, MLBI memiliki jumlah lembar saham 
paling sedikit setelah jumlah saham DLTA.

Terdapat 22 perusahaan yang rata-rata $E P S$-nya di bawah rata-rata EPS industri costumer goods yaitu AISA, CEKA, INDF, MYOR, PSDN, SKLT, HMSP, INAF, UNVR, KDSI, STTP, ULTJ, GGRM， DVLA，KAEF，KLBF, PYFA, SQBI, TSPC, MRAT, TCID, dan LMPI. Diantara perusahaan tersebut rata-rata EPS terendah dimiliki oleh PT Langgeng Makmur Industri Tbk (LMPI) yaitu sebesar Rp. 4,16.LMPI selama tahun 2008 sampai dengan tahun 2012 memiliki laba bersih yang berfluktuasi.Selain itu, jumlah saham yang dimiliki oleh LMPI sampai tahun 2012 mencapai 1.008.517.669 lembar saham. Jumlah ini terbilang banyak dengan rata-rata laba bersih yang dihasilkan selama tahun 2008 sampai dengan tahun 2012 hanya Rp. 3.825.000.000 sehingga tingkat keuntungan perlembar sahamnya menjadi sedikit.

\section{Perkembangan EPS Perusahaan} Sektor Industri Consumer Goods Tahun 2008 - 2012

Rata-rata EPS dari 26 perusahaan sektor Consumer Goods terhitung Rp 29.907,70. Perusahaan yang memiliki rata-rata di atas ratarata harga saham industri antara lain DLTA, MLBI, GGRM, MERK, dan SQBI. Rata-rata harga saham tertinggi selama tahun 2008-2012 dimiliki oleh PT Multi Bintang Indonesia Tbk (MLBI) yaitu sebesar Rp 320.090. Hal ini mengindikasikan bahwa saham MLBI banyak diminati oleh investor. Salah satu daya tarik MLBI yaitu kemampuannya dalam menghasilkan laba per saham yang selalu stabil dan meningkat dari tahun ke tahun, selama periode penelitian yaitu 2008 sampai tahun 2012 rata-rata laba bersih per sahamnya mencapai $\mathrm{Rp} 21.562,55$ yang merupakan rata-rata laba bersih per saham tertinggi dalam industri costumer goods.

Perusahaan yang rata-rata harga sahamnya berada di bawah rata-rata harga saham industri 
costumer goods antara lain AISA, CEKA, INDF, MYOR, PSDN, SKLT, HMSP, INAF, UNVR, KDSI, STTP, ULTJ, DVLA, KAEF, KLBF, PYFA, SQBB, TSPC, MRAT, TCID, dan LMPI. Diantara perusahaan tersebut rata-rata harga saham terendah selama tahun 20082012 dimiliki oleh PT Pyramid Farma Tbk (PYFA) yaitu Rp 128. Jika dilihat dari kemampuan menghasilkan laba, rata-rata laba bersih per saham PYFA selama tahun 2008 sampai dengan tahun 2012 sebesar Rp 7,76 ini jumlah yang kecil jika dibandingkan dengan perusahaan yang lainnya.

\section{Uji Asumsi Klasik}

Metode analisis data yang digunakan dalam penelitian ini adalah metode analisis statistik yang menggunakan persamaan regresi data panel melalui software Eviews versi 6. Model regresi yang baik memiliki estimator yang BLUE (Best Linier Unbiased Estimator), artinya suatu penaksiran adalah $B L U E$ jika efisien yaitu tidak bias maupun mempunyai varians minimum. Untuk mendapatkan hasil yang lebih efisien, data ditransformasikan dalam bentuk logaritma natural.

\section{Pemilihan Model Regresi Data Panel}

Pemilihan model berdasarkan uji Chow, nilai probabilitas cross section chi-square dan nilai cross section chi-square sebesar $0.0000<$ 0.05, berarti $\mathrm{H}_{0}$ ditolak sehingga pendekatan yang diambil adalah Fixed Effect Model. Berdasarkan uji Hausman, nilai probabilitas cross section random (p-value) sebesar $0.8074>0.05$, berarti $\mathrm{H}_{0}$ diterima sehingga pendekatan yang diambil adalah Random Effect Model.Berdasaarkan kedua uji pemilihan model tersebut model yang tepat sebagai pendektan yang dipakai adalah Random Effect Model.

Hasil uji asumsi klasik regresi berikut.:

1. Hasil perhitungan Jarque-Berra untuk modelsebesar 154.6503 dimana lebih kecil dari nilai $c h i$ square tabel yaitu 156.51, 
berarti $\mathrm{H}_{0}$ diterima sehingga dapat disimpulkan data terdistribusi normal.

2. Hasil perhitungan nilai koefisien korelasi antarvariabel bebas berada di bawah 0.8 sehingga dapat disimpulkan bahwa model regresi tidak terjadi multikolinieritas.

Berdasarkan hasil uji heterokedastisitas dihasilkan nilai probabilitas chi square 0.0607 > 0.05 , berarti $\mathrm{H}_{0}$ diterima sehingga tidak mengalami heterokedastisitas.Nilai DurbinWatson dari model sebesar 1.192678, dimana hasil itu berada di antara -2 dan $+2(-2 \leq \mathrm{DW} \leq+2)$, berarti tidak terjadi autokorelasi.

\section{Persamaan Regresi}

Persamaan regresi Random Effect Model yang dihasilkanyaitu :

LN_HS $=3.280817+0.155613$ LN_CR+ 0.190480 LN_DER + 0.871264 LN_EPS $+\varepsilon_{i t}$

Persamaan di atas dapat diartikan sebagai berikut :

1. Konstanta sebesar 3.280817. Hal ini berarti apabila variabel LN_CR, LN_DER, dan
LN_EPS bernilai 0, maka LN_HS sebesar 3.280817.

2. Koefisien LN_CR sebesar 0.155613. Hal ini berarti jika terjadi perubahan kenaikan LN_CR sebesar 1 poin, maka akan menaikkan LN_HS sebesar 0.155613 dengan asumsi variabel lainnya tetap. Ini artinya bahwa antara $C R$ dan harga saham menunjukkan hubungan yang searah (positif) artinya setiap kenaikan $C R$ sebesar 1\% akan diikuti oleh kenaikan harga saham sebesar $0.155613 \%$ dan sebaliknya penurunan $\quad C R \quad 1 \%$ akan mengakibatkan penurunan harga saham sebesar $0.155613 \%$.

3. Koefisien LN_DER sebesar 0.190480. Hal ini berarti jika terjadi perubahan kenaikan LN_DER sebesar 1 poin, maka akan menaikkan LN_HS sebesar 0.190480 dengan asumsi variabel lainnya tetap. Ini artinya bahwa antara $D E R$ dan harga saham menunjukkan hubungan yang searah (positif) 
artinya setiap kenaikan $D E R$

sebesar 1\% akan diikuti oleh

kenaikan harga saham sebesar

$0.190480 \%$ dan sebaliknya

penurunan DER 1\% akan

mengakibatkan penurunan

harga saham sebesar

$0.190480 \%$.

4. Koefisien LN_EPS sebesar 0.871264. Hal ini berarti jika terjadi perubahan kenaikan LN_EPS sebesar 1 poin, maka akan menaikkan LN_HS sebesar 0.871264 dengan asumsi variabel lainnya tetap. Ini artinya bahwa antara EPS dan harga saham menunjukkan hubungan yang searah (positif) artinya setiap kenaikan EPS sebesar 1\% akan diikuti oleh kenaikan harga saham sebesar $0.871264 \%$ dan sebaliknya penurunan EPS $1 \%$ akan mengakibatkan penurunan harga saham sebesar $0.871264 \%$.

5. $\varepsilon_{i t}$ merupakan nilai yang ditunjukkan oleh random effect (cross) atau nilai residualyang dimiliki oleh masing-masing perusahaan dimana setiap perusahaan memiliki nilai residual yang berbeda dan jumlah residual dari seluruh perusahaan sampel bernilai 0 .

\section{Pengujian Hipotesis}

\section{Uji t (Uji parsial)}

a. Variabel $C R(\mathrm{X} 1)$ memiliki nilai t hitung $0.701736<\mathrm{t}$ tabel 1.97867. Nilai probabilitas sebesar $0.4841>$ signifikan 0.05, maka Ho diterima yang berarti $C R$ tidak berpengaruh signifikan secara parsial terhadap harga saham perusahaan sektor Consumer Goods.

b. Variabel DER (X2) memiliki nilai $\mathrm{t}$ hitung $1.078014<\mathrm{t}$ tabel 1.97867 . Nilai probabilitas sebesar 0.2831 > signifikan 0.05, maka Ho diterima yang berarti DER tidak berpengaruh signifikan secara parsial terhadap harga saham perusahaan sektor Consumer Goods.

c. Variabel EPS (X3) memiliki nilai t hitung $13.15962>\mathrm{t}$ 


tabel $1.97867 . \quad$ Nilai
probabilitas sebesar $0.000<$
signifikan 0.05 , maka Ho
ditolak yang berarti EPS
berpengaruh signifikan
secara parsial terhadap
harga saham perusahaan
sektor Consumer Goods.

Uji F (Uji Simultan)

Nilai statistik F hitung $61.56957>$

$\mathrm{F}$ tabel 2.68. Nilai probabilitas (Fstatistic) $0.0000<$ signifikan 0.05 , maka Ho ditolak yang berarti bahwa variabel $C R, D E R$, dan EPS berpengaruh signifikan terhadap harga saham perusahaan sektor Consumer Goods secara simultan.

\section{Koefisien Determinasi $\left(\mathbf{R}^{\mathbf{2}}\right)$}

Nilai $\mathrm{R}^{2}$ yang disesuaikan (Adjusted

$R$-square) sebesar 0.584820 atau $58.4820 \%$. Hal ini dapat disimpulkan bahwa variabel bebas yang terdiri $C R, D E R$, dan EPS dapat menjelaskan variabel terikat yaitu harga saham perusahaan sektor Consumer Goods sebesar $58.4820 \%$, sedangkan sisanya sebesar $41.5180 \%$ dijelaskan oleh variabel atau faktor lain di luar penelitian.
Pengaruh Kemampuan Bayar Kewajiban Jangka Pendek (CR) terhadap harga saham

Variabel $\quad C R \quad$ memiliki hubungan yang positif namun tidak berpengaruh signifikan terhadap harga saham perusahaan sektor Consumer Goods.Hasil penelitian ini sejalan dengan hasil penelitian yang telah dilakukan oleh Sidabutar (2012) dan Sipayung (2012).CR yang tinggi menggambarkan likuiditas perusahaan yang baik, akan tetapi $C R$ yang tinggi juga mengindikasikan adanya penumpukan persediaan dan piutang. Kedua perspektif ini membuat $C R$ yang diukur melalui kemampuan aktiva lancar perusahaan dalam memenuhi kewajiban jangka pendek kurang dapat dijadikan pertimbangan untuk memproyeksi harga saham ke depannya karena adanya.

\section{PengaruhKewajiban Bayar Bunga (DER) terhadap harga saham}

Variabel DER memiliki hubungan positif dan tidak 
berpengaruh signifikan terhadap pemegang saham. Ini akan harga saham.Hasil penelitian ini mendorong investor untuk sejalan dengan hasil penelitian yang melakukan investasi yang lebih telah dilakukan oleh Sidabutar besar lagi sehingga harga saham (2012). Untuk menilai rasio ini perusahaan akan meningkat.

perlu dipertimbangkan juga stabilitas laba perusahaan. Kewajiban bukan sesuatu yang buruk jika dapat memberikan keuntungan kepada pemiliknya.Pertimbangan $D E R$ yang melibatkan pertimbangan tingkat laba membuat $D E R$ kurang bisa dijadikan acuan dalam berinvestasi.

Pengaruh Laba Per Lembar Saham (EPS) terhadap harga saham

Variabel EPS memiliki hubungan positif dan berpengaruh signifikan terhadap harga saham. Hasil penelitian ini sesuai dengan hasil penelitian yang telah dilakukan oleh Simatupang (2010), Asri (2011), Amanda \& Pratomo (2013), dan Sasono (2013). Makin tinggi nilai Laba Per Lembar Saham tentu saja menggembirakan pemegang saham karena makin Pengaruh $C R, D E R$, dan EPS terhadap Harga Saham

Variabel Kemampuan Bayar Kewajiban Jangka Pendek (CR), Kewajiban Bayar Bunga (DER), dan Laba Per Lembar Saham (EPS) memiliki pengaruh signifikan secara simultan dengan nilai kontribusi sebesar $58.4820 \%$ dalam mempengaruhi harga saham. Kinerja perusahaan yang baik dapat meningkatkan nilai jual perusahaan sehingga banyak investor yang akan berinvestasi di perusahaan tersebut. Permintaan saham yang meningkat akan membuat harga saham akan meningkat. Sebaliknya, perusahaan yang memiliki kinerja yang buruk berpotensi mengurangi kepercayaan investor terhadap suatu perusahaan sehingga nilai sahamnya kurang diminati dan akan terus mengalami penurunan harga saham. 


\section{PENUTUP}

Perkembangan Kemampuan Bayar Kewajiban Jangka Pendek (CR), Kewajiban Bayar Bunga (DER), Laba Per Lembar Saham (EPS) dan harga saham dari perusahaan industry consumerr goods yang listing di BEI tahun 2008 sampai dengan tahun 2012.

Rata-rata Kemampuan Bayar Kewajiban Jangka Pendek (CR) dari 26 perusahaan sektor Consumer Goods terhitung 3,04 kali.Terdapat 10 perusahaan yang rata-rata Kemampuan Bayar Kewajiban Jangka Pendek (CR) selama tahun 2008-2012 berada diatas rata-rata industri costumer goods. Rata-rata Kemampuan Bayar Kewajiban Jangka Pendek (CR) tertinggi dimiliki oleh PT Mandom Indonesia Tbk (TCID) yaitu sebesar 9.10 kali. Dan ratarata Kemampuan Bayar Kewajiban Jangka Pendek (CR) terendah dimiliki oleh PT Unilever Indonesia Tbk (UNVR) yaitu sebesar 0.85 kali.

Rata-rata Kewajiban Bayar Bunga (DER) dari 26 perusahaan sektor Consumer Goods terhitung 0.81 kali.Terdapat 11 perusahaan yang rata-rata Kewajiban Bayar Bunga (DER) berada di atas ratarata Kewajiban Bayar Bunga (DER) industri costumer goods. Rata-rata Kewajiban Bayar Bunga (DER) tertinggi dimiliki oleh PT Multi Bintang Indonesia Tbk (MLBI) yaitu sebesar 2.84 kali. Dan ratarata $C R$ terendah dimiliki oleh $\mathrm{PT}$ Mandom Indonesia Tbk (TCID) yaitu sebesar 0.12 kali.

Rata-rata Laba Per Lembar Saham (EPS) dari 26 perusahaan sektor Consumer Goods terhitung $\mathrm{Rp} \quad$ 2.136,45.Terdapat empat perusahaan yang rata-rata Laba Per Lembar Saham (EPS) berada di atas rata-rata Laba Per Lembar Saham (EPS) industri costumer goods. Rata-rata Laba Per Lembar Saham (EPS) tertinggi dimiliki oleh PT Multi Bintang Indonesia Tbk (MLBI) yaitu sebesar Rp 21.562,55. Rata-rata Laba Per Lembar Saham (EPS) terendah dimiliki oleh PT Langgeng Makmur Industri Tbk (LMPI) yaitu sebesar Rp. 4,16. 
Rata-rata Laba Per Lembar Saham (EPS) dari 26 perusahaan sektor Consumer Goods terhitung Rp. 29.907,70. Terdapat lima perusahaan yang memiliki rata-rata di atas rata-rata harga saham industri. Rata-rata harga saham tertinggi selama tahun 2008-2012 dimiliki oleh PT Multi Bintang Indonesia Tbk (MLBI) yaitu sebesar Rp. 320.090. Rata-rata harga saham terendah selama tahun 2008-2012 dimiliki oleh PT Pyramid Farma Tbk (PYFA) yaitu Rp. 128.

Variabel Kemampuan Bayar Kewajiban Jangka Pendek (CR) memiliki t hitung $0.701736<\mathrm{t}$ tabel 1.97867 dan tingkat sig $0.4841>$ sig 0.05, sehingga Kemampuan Bayar Kewajiban Jangka Pendek (CR) tidak berpengaruh signifikan secara parsial terhadap harga saham perusahaan perusahaan sektor industry Consumer Goods yang terdaftar di BEI.

Variabel Kewajiban Bayar Bunga (DER) memiliki $t$ hitung $1.078014<\mathrm{t}$ tabel 1.97867 dan tingkat sig $0.2831>\operatorname{sig} 0.05$, sehingga Kewajiban Bayar Bunga (DER) tidak berpengaruh signifikan secara parsial terhadap harga saham perusahaan perusahaan sektor industry Consumer Goods yang terdaftar di BEI.

Variabel Laba per Lembar Saham (EPS) memiliki $\mathrm{t}$ hitung $13.15962>\mathrm{t}$ tabel 1.97867 dan tingkat sig $0.00<\operatorname{sig} 0.05$, sehingga Laba per Lembar Saham (EPS) berpengaruh signifikan secara parsial terhadap harga saham perusahaan perusahaan sektor industry Consumer Goods yang terdaftar di BEI.

Variabel Kewajiban Bayar Bunga (DER), Kewajiban Bayar Bunga (DER), dan Laba Per Lembar Saham (EPS)memiliki nilai $\mathrm{F}$ hitung $61.56957>\mathrm{F}$ tabel 2.68 dan tingkat sig $0.00<0.05$, sehingga berpengaruh signifikan secara simultan terhadap harga saham perusahaan perusahaan sektor industri Consumer Goods yang terdaftar di BEI. 


\section{DAFTAR PUSTAKA}

Amanda, \& Pratomo, Wahyu A. (2013). Analisis Fundamental Dan Resiko Sistematik Terhadap Harga Saham Perbankan Yang Terdaftar Pada Indeks LQ 45. Jurnal Ekonomi dan Keuangan, Volume 1 No 3, Februari 2013

Anonim. (2009). $\underline{\text { Krisis }}$ Global 2008. [Online]. Tersedia: http://www.indonesiarecovery.com/krisis-keuangan-global-2008/krisis2008-terparah-sejak-the-great-depression/7-krisis-global-2008.html [1

Asri, Jatnika D. (2011). Pengaruh Earning Per Share (EPS), Debt To Equity Ratio (DER), dan Pertumbuhan Asset Terhadap Perubahan Harga Saham (Studi Kasus pada Perusahaan Sektor Pertanian yang Listing di Bursa Efek Indonesia Tahun 2003-2008). Jurnal Ekono Insentif Kopwil4, Volume 5 No. 1, Juli 2011, ISSN: 1907 - 0640, halaman 1-7

Babaei, Zahra. (2013). Correlation Between Financial Leverage And Firm Value In Companies In The Tehran Stock Exchange. Research Journal of Finance and Accounting Vol.4, No.5, 2013, page 39 - 49.

Bursa Efek Indonesia. (2010). Buku Panduan Indeks BEI.Jakarta : BEI

Bursa Efek Indonesia.ICaMel 2008-2012. Jakarta : BEI

Bursa Efek Indonesia.IDX Statistik 2007-2012. Jakarta :BEI

Chang, Hsu Ling, et al. (2008). The Relationship between Stock Price and EPS: Evidence Based on Taiwan Panel Data. Economics Bulletin, Vol. 3, No. 30, 11 February 2008, page $1-12$

Gujarati, Damodar N., \& Porter, Dawn C. (2010). Essentials of Econometrics $\left(4^{\text {th }}\right.$ ed). New York: McGraw Hill International Edition

Heidar, Seyed., et al. (2011). Fitting the Relationship between Financial Variables and Stock Price through Fuzzy Regression Case study: Iran 
Khodro Company. International Journal of Business and Social Science Vol. 2 No. 11, June 2011

Juanda, Bambang, \& Junaidi. (2012). Ekonometrika Deret Waktu Teori \& Aplikasi.Bogor : IPB Press Kodrat, David Sukardi, \& Indonanjaya, Kurniawan. (2010). Manajemen Investasi: Pendekatan Teknikal dan Fundamental untruk Analisis saham. Yogyakarta: Graha Ilmu.

Kuswadi. (2005). Meningkatkan Laba Melalui Pendekatan Akuntansi Keuangan dan Akuntansi Biaya.Jakarta : PT Elex Media Komputindo

Lind, Douglas A., et al. (2009). Teknik-Teknik Statistika Dalam Bisnis dan Ekonomi Menggunakan Kelompok Data Global (Buku 2 Edisi 13). Jakarta: Salemba Empat.

Menaje, Placido M. (2012). Impact of Selected Financial Variables on Share Price of Publicly Listed Firms in the Philippines. American International Journal of Contemporary Research Vol. 2 No. 9, September 2012, page $98-104$

Miranda, Andini. (2011). Pengaruh Earning Per Share, Dividend Per Share, dan Financial Leverage terhadap Harga Saham pada Perusahaan Food \& Beverage Yang Terdaftar di Bursa Efek Indonesia. Skripsi pada Fakultas Ekonomi Universitas Sumatera Utara : tidak diterbitkan.

Nasehudin, Toto S., \& Gozali, Nanang (2012). Metode Penelitian Kuantitatif. Bandung :Pustaka Setia.

Oktaviana, Ulfi K., \& Wahyuni, Nanik. (2011). Pengaruh Perubahan Komposisi Jakarta Islamic Index terhadap Return Saham.Jurnal eLQUDWAH, Volume 1 Nomor 5, April 2011

Raharjo, Sugeng. (2011).Analisis Pengaruh Variabel Ekonomi Makro dan Rasio Keuangan terhadap Harga Saham pada Perusahaan Manufaktur di Bursa Efek Indonesia. Jurnal. Repository STIE Surakarta 
Sasono, Hadi. (2013). Pengaruh Beberapa Rasio Keuangan terhadap Harga Saham pada Perusahaan Otomotif yang Go Public di PT. Bursa Efek Indonesia. Jurnal Manajemen dan Bisnis (JMB), Volume 1 Nomor 1, Tahun 2013.

Sekaran, Uma. (2011). Research Methods For Business (Metodologi Penelitian untuk Bisnis) (Buku 1 Edisi 4). Jakarta: Salemba Empat. .(2011). Research Methods For Business (Metodologi Penelitian untuk Bisnis) (Buku 2 Edisi 4). Jakarta: Salemba Empat.

Setiawan dan Kusrini, Dwi E. (2010). Ekonometrika. Yogyakarta : ANDI.

Sidabutar, Chrystine A. (2012). Pengaruh Current Ratio (CR), Debt To Equity Ratio (DER), dan Return On Equity (ROE) terhadap Harga Saham pada Perusahaan Manufaktur Industri Makanan dan Minuman yang Terdaftar di Bursa Efek Indonesia. Skripsi pada Fakultas Ekonomi Universitas Sumatera Utara : tidak diterbitkan.

Simatupang, Stevanie T. (2010). Pengaruh Rasio Keuangan dan Ukuran Perusahaan terhadap Harga Saham Industri Manufaktur yang Terdaftar di Bursa Efek Indonesia.Skripsi pada Fakultas Ekonomi Universitas Sumatera Utara : tidak diterbitkan.

Sipayung, Emmy M. (2012).Pengaruh Laba Per Lembar Saham dan Rasio Lancar terhadap Harga Saham pada Perusahaan Pertambangan LQ45.Skripsi pada Fakultas Ekonomi Universitas Komputer Indonesia : tidak diterbitkan.

Situmorang, M. P. (2008).Pengantar Pasar Modal. Jakarta : Mitra Wacana Media

Sugiyono. (2012). Metode Penelitian Kuantitatif, Kualitatif dan R\&D (Cetakan 15). Bandung: Penerbit Alfabeta. 
Sujatmiko, Yopi. (2011). Pengaruh Current Ratio, Debt to Equity Ratio, dan Return to equity Terhadap Harga Saham Studi Kasus Pada Perusahaan Industri Barang Konsumsi yang Listing di BEI Tahun 2006 - 2009. Skripsi pada Institut Manajemen Telkom : tidak diterbitkan.

Sunyoto, Danang. (2011). Analisis Regresi dan Uji Hipotesis. Yogyakarta: CAPS.

Van Horne, James. C., \& Machowics, John M. (2007). Prinsip-Prinsip Manajemen Keuangan (Edisi 12). Jakarta: Salemba Empat.

Zikmund, William G., et al. (2010). Business Research Methods. Ohio: SouthWestern. 